Article

\title{
Intramuscular Boosting with hIFN-Alpha $2 b$ Enhances BCGphipps-Induced Protection in a Murine Model of Leprosy
}

\author{
Gloria G. Guerrero ${ }^{1, *}$, Javier Rangel-Moreno ${ }^{2}{ }^{\mathbb{D}}$, Sergio O. Islas-Trujillo ${ }^{3}$ and Oscar Rojas-Espinosa ${ }^{3}$ \\ 1 Unidad Académica de Ciencias Biológicas, Universidad Autónoma de Zacatecas, Av. Preparatoria S/N, Col. \\ Agronomicas, Zacatecas 98066, Mexico \\ 2 Division of Allergy, Immunology and Rheumatology, Department of Medicine, University of Rochester \\ Medical Center, 601 Elmwood Avenue, Rochester, NY 14642, USA; \\ Javier_Rangel-Moreno@urmc.rochester.edu \\ 3 Departamento de Inmunología, Instituto Politécnico Nacional, Carpio y Plan de Ayala, Escuela Nacional de \\ Ciencias Biológicas, Colonia Santo Tomas, Ciudad de Mexico 11340, Mexico; \\ trujiser2@yahoo.com.mx (S.O.I.-T.); rojas_espinosa@hotmail.com (O.R.-E.) \\ * Correspondence: gloguerrero9@gmail.com or gloriaguillermina@uaz.edu.mx; Tel.: +52-492-156-4376
}

\section{check for}

updates

Citation: Guerrero, G.G.;

Rangel-Moreno, J.; Islas-Trujillo, S.O.;

Rojas-Espinosa, O. Intramuscular

Boosting with hIFN-Alpha $2 b$

Enhances BCGphipps-Induced

Protection in a Murine Model of

Leprosy. Microbiol. Res. 2021, 12,

711-726. https://doi.org/10.3390/

microbiolres12030051

Academic Editors: Gene S. Tan and Michael Calcutt

Received: 4 May 2021

Accepted: 22 July 2021

Published: 30 August 2021

Publisher's Note: MDPI stays neutral with regard to jurisdictional claims in published maps and institutional affiliations.

Copyright: (c) 2021 by the authors. Licensee MDPI, Basel, Switzerland. This article is an open access article distributed under the terms and conditions of the Creative Commons Attribution (CC BY) license (https:// creativecommons.org/licenses/by/ $4.0 /)$.

\begin{abstract}
Host immunity to Mycobacterium leprae encompasses a spectrum of mechanisms that range from cellular immunity-driven protection to damage associated with humoral immunity as in type-2 leprosy reactions. Although type I interferons (IFNs) participate in eliminating intracellular pathogens, their contribution to the production of antibodies and $\mathrm{CD}^{+} \mathrm{FOXP3}^{+}$regulatory $\mathrm{T}$ cells (Tregs) in BCG vaccine-mediated protection in leprosy is unknown. BCGphipps (BCGph) priming followed by intramuscular hIFN- $\alpha 2 b$ boost significantly reduced lesion size and Mycobacterium lepraemurium growth in the skin. T follicular regulatory cells (TFR), a subset of Tregs induced by immunization or infection, reside in the germinal centers (GCs) and modulate antibody production. We found impaired Treg induction and improved GCs in draining lymph nodes of BCGph primed and hIFN- $\alpha 2 b$ boosted mice. Moreover, these mice elicited significant amounts of IL- 4 and IL-10 in serum. Thus, our results support the adjuvant properties of hIFN- $\alpha 2 b$ in the context of BCGph priming to enhance protective immunity against skin leprosy.
\end{abstract}

Keywords: Mycobacterium lepraemurium; murine leprosy; interferon alpha; BCGphipps; germinal centers; regulatory T cells

\section{Introduction}

Mycobacterium leprae and Mycobacterium lepromatosis, the etiological agents of human leprosy [1,2], affect the skin and peripheral nerves [3]. Although multidrug treatments (MDT) for leprosy are available, the number of new cases remains stable (700,000 per year). Furthermore, the lack of an effective diagnostic procedure makes tracking of M. leprae transmission difficult [4-7]. The genetic predisposition to early leprosy [8] emphasizes the need for an opportune diagnosis and development of low-cost immunotherapies to reduce leprosy incidence in developed countries $[9,10]$. The spectrum of clinical manifestations in leprosy correlates with the type of immune response elicited. For example, tuberculoid leprosy (TT), characterized by a dominant Th1 response, restricts bacilli growth via IFN- $\gamma-$ driven activation of microbicidal functions of macrophages. In contrast, the production of classic Th2 cytokines (IL-4 and IL-10) has been associated with loss of protection and enhanced bacillary growth in disseminated lepromatous leprosy (LL) [10]. There are also intermediate subtypes that represent a mixture of Th1 and Th2 responses [10].

Infection of mice with M. lepraemurium (MLM) [11,12] has been used to study immunological mechanisms of human leprosy [11-13], despite the fact that MLM does not show tropism for peripheral nerves [11,13] as M. leprae does [14]. Nevertheless, both mycobacteria are non-cultivable and grow slowly in the host, doubling their numbers in 1-3 weeks. 
Experimental subcutaneous infection with small doses of bacteria closely mimics the natural disease that usually occurs when disruption of barriers facilitates mycobacterial colonization, triggering an immune reaction at a peripheral level [13,15-17]. While cellmediated immunity (CMI) is impaired, humoral immunity is practically unaffected in human and murine leprosy [18]. In addition, Th1- or Th2-cells, other T lymphocytes, shape the host immunity to $M$. leprae infection $[18,19]$.

It is intriguing how M. leprae influences host immunity in the different subtypes of mycobacterial disease. One hypothesis is that the pathogen downregulates host humoral and cellular immunity to infect the skin and peripheral nerves $[3,14,15]$. There is also evidence that the bacillus impairs macrophage activation. It also decreases the expression of TNF-alpha and molecules such as prostaglandins which induce the production of IL-1 $\beta$ and reactive oxygen and nitrogen intermediates (ROI and $\mathrm{RNI}$ ), critical in the mycobactericidal functions of macrophages [20-22].

Humoral responses generated in the GCs of secondary and tertiary lymphoid tissues participate in the protective immunity against pathogens [23-26]. A recent report on leprosy highlighted the critical role of Tregs in the inhibition of Th1 and Th17 cell responses [19]. Indeed, the balance between these subsets of T cells at the GCs [27-29] dictates the protective or pathological outcomes of infectious and autoimmune diseases [30,31] and is critical for the development of therapies to induce protective immunity [26,27]. In particular, $\mathrm{T}$ helper follicular cells (TFH) and especially $\mathrm{T}$ follicular regulatory cells (TFR) modulate the GC response to induce long-lasting humoral immune responses while preventing the production of autoantibodies [32,33]. Given that type I IFN is associated with the generation of both TFH and Tregs, it emerges as a promising adjuvant to stimulate TFH responses in the GCs in the context of BCG vaccination [34].

Mucosal administration of type I IFNs induces dendritic cell maturation and generation of CXCR5 ${ }^{+} \mathrm{CD}^{+} \mathrm{TFH}$, facilitating GC development and the production of high-affinity antibodies in lymph nodes [34]. In contrast, type I IFNs abrogate host immunity in human tuberculosis by inhibiting the production of inducible nitric oxide synthase (iNOS), IL-12p40, IL-1A, and IL-1 $\beta$, while inducing IL-10 and IL-1R antagonists [35-38]. Thus, the participation of type I IFNs is context-dependent [38-42]. Type I IFNs are produced at a steady level, but once an intracellular pathogen invades the host, several heterogeneous and complex anti-viral or anti-bacterial innate responses are induced [43-48], including antibody class switching, somatic hypermutation, and enhancement of antigen availability in the GCs that will lead to strong and effective antibody responses $[34,49]$.

We previously reported the protection conferred by successive intramuscular IFN boosting in mice vaccinated with Mycobacterium bovis BCG and challenged with MLM [42] or against aerosolized $M$. tuberculosis challenge [41]. In mice challenged with MLM, protection correlated with enhanced production of iNOS, nitric oxide, and IgG3 antibodies [42]. In the context of the M. tuberculosis challenge, the protected mice elicited a Th1 response [41]. In a more recent study, type I IFNs modulated autophagy and metabolism in leprosy [50]. We decided in this study to further investigate the protection against murine leprosy induced by vaccination with $M$. bovis BCGphipps (BCGph) and a pharmaceutical presentation of human IFN- $\alpha 2 b$ [51]. In recent studies, a recombinant BCG that expresses human IFN- $\alpha$ $2 \mathrm{~b}$ was used to successfully treat bladder cancer [51-55]. Consistent with these data, our goal in this study was to analyze the protection induced by BCGph priming and hIFN- $\alpha$ $2 \mathrm{~b}$ boosting in a murine model of leprosy. Altogether, our results envisage the potential of BCGph subcutaneous priming and intramuscular hIFN- $\alpha 2 b$ boosting to induce protective immunity against human leprosy.

\section{Material and Methods}

\subsection{Animals}

Specific pathogen-free Balb/c mice were bred and housed in the Animal facilities of the Escuela Nacional de Ciencias Biológicas, Instituto Politécnico Nacional in Mexico City. 
All animal experiments were performed after approval (07 March 2014) by the Institutional Animal Care and Management Committee (CIE-ENCB ZOO 016/2014).

\subsection{Microorganisms}

The BCG Phipps strain (ATCC ${ }^{\circledR} 35744^{\mathrm{TM}}$ ) (BCGph) is a variant of the BCG strain that has lost the region RD1 which encodes ESAT-6 and CFP10, with the lowest number of T cell epitopes, 316, versus BCG Tokyo, 359, and BCG Pasteur, 331, (Zhang et al., 2013) [51] and was provided by Dr. Hernández-Pando (INCMNSZ, Mexico City, MX). Vaccine suspensions were then stored at $-80^{\circ} \mathrm{C}$ until use. Mycobacterium lepraemurium (MLM) non-cultivable strain was isolated from the spleen of mice bearing a four-month infection via a procedure described by Prabhakaran et al., 1976 [56], followed by purification using the percoll isolation procedure described by Draper P., 1980 [57]. Briefly, $4 \mathrm{~g}$ of splenic tissue were suspended in $20 \mathrm{~mL}$ of $0.2 \mathrm{M}$ sucrose and ground in a glass Potter-Elvehjem type homogenizer. The resulting suspension was centrifuged for $20 \mathrm{~min}$ at $150 \times g$ to remove cell debris (Sorvall RV5B, rotor HB4) (Sorvall Instruments, Wilmington, DE, USA). Then, $9 \mathrm{~mL}$ of the supernatant was overlaid on $12 \mathrm{~mL}$ of $0.3 \mathrm{M}$ sucrose, and the tubes were centrifuged at $3500 \times g$ for $10 \mathrm{~min}$ at $4-10{ }^{\circ} \mathrm{C}$ (Sorvall RC5B). The resulting bacilli-rich pellet was resuspended in $20 \mathrm{~mL}$ of $0.2 \mathrm{M}$ sucrose, and $9 \mathrm{~mL}$ aliquots were overlaid on $12 \mathrm{~mL}$ of $1.5 \mathrm{M}$ $\mathrm{KCl}$. Then, the tube was centrifuged at $4{ }^{\circ} \mathrm{C}$ for $10 \mathrm{~min}$ at $3500 \times \mathrm{g}$. The bacilli were collected, washed three times with phosphate-buffered-saline (PBS) (0.01 M Na/K phosphate, $0.15 \mathrm{M}$ $\mathrm{NaCl}, \mathrm{pH} 7.4$ ), and resuspended in $40 \mathrm{~mL}$ of a solution containing a mixture of Percoll (3 parts) and $0.1 \%$ Tween 80 (7 parts). The suspension was centrifuged at $23,000 \times g$. The bacillary pellet was collected and washed five times with PBS until eliminating the Percoll. The purity of the bacillary preparation was confirmed by Ziehl-Neelsen staining. The purified bacillary suspension was prepared in synthetic 7H9 Middlebrook brothOADC medium (DIFCO, Detroit, MI, USA) (7H9-OADC medium) and quantified via a nephelometric reference curve prepared with known quantities of bacteria. The bacillary suspension was aliquoted and frozen at $-20{ }^{\circ} \mathrm{C}$, until ready for use.

\subsection{Immunizations}

Groups of eight-week-old Balb/c mice $(n=6)$ were subcutaneously immunized with $8 \times 10^{3}$ colony-forming units (CFU) of BCGphipps in $200 \mu \mathrm{L}$ sterile PBS. One month later, each group of mice was intramuscularly boosted during three consecutive days (30, 31, 32 days after vaccination) with $100 \mu \mathrm{L}$ of PBS or with 100, 200, or 300 international units (IU) of hIFN- $\alpha 2 b$ (Urifron, Probiomed, Azcapotzalco, Mexico City, Mexico).

\subsection{M. lepraemurium Challenge}

For the challenge experiments, mice were inoculated intradermally with $2 \times 10^{6}$ viable MLM in $20 \mu \mathrm{L}$ of PBS. Then, the mice were housed in standard conditions and supplied with purified water and Purina rodent chow chips (Cuautitlan Izcalli, Mexico) ad libitum. The infected mice were monitored for eight weeks, the time points when lesions were evident in the skin of infected animals. Disease progression was variable in the mice and correlated with experimental therapies (PBS, BCGph, or hIFN- $\alpha 2 b$ ).

\subsection{Enzyme-Linked Immunosorbent Assays (ELISA)}

Antibodies in the sera of MLM-infected mice were measured by indirect enzymelinked immunosorbent assays (ELISA). Briefly, 96-well plates (Nunc, Rochester, NY, USA) were coated overnight at $4^{\circ} \mathrm{C}$, with $1.0 \mu \mathrm{g}$ of peptidoglycolipids dissolved in ethanol [38]. After ethanol evaporation at room temperature [37], non-specific binding was blocked with 3\% non-fat milk in PBS from 2 to $3 \mathrm{~h}$. After discarding the blocking solution, $0.1 \mathrm{~mL}$ of the sera diluted (1:100) in 1\% non-fat milk in PBS was added to the wells and incubated overnight at $4{ }^{\circ} \mathrm{C}$. Then, plates were extensively washed with PBS, and bound antibodies were detected with $0.1 \mathrm{~mL}$ of anti-mouse IgG (1:4000, BD 550487, BD Pharmingen, San Diego, CA, USA), IgG1-HRP (1:2500, ab 97240, abcam, Cambridge, MA, USA), IgG2a- 
HRP (1:2500, ab97245, abcam), IgG2b-HRP (1:2500, ab97250, abcam), or IgG3-HRP (1:2500, ab97260, abcam), or biotin-conjugated rat anti-mouse IgA monoclonal antibody (1:1000, BD 550487, BD Pharmingen), followed by a horseradish peroxidase (HRP)-conjugated rat anti-mouse Ig antibody (1:1000, BD 550487, BD Pharmingen) or avidin-HRP (ab 59653, abcam) The chromogenic substrate, tetramethyl-benzidine in $0.05 \mathrm{M}$ citrate-phosphate buffer ( $\mathrm{pH} 5.2$ ), supplemented with $0.01 \%$ hydrogen peroxide $\left(\mathrm{H}_{2} \mathrm{O}_{2}\right)$, was added to the wells for color development. The reaction was stopped with $1 \mathrm{M} \mathrm{H}_{3} \mathrm{PO}_{4}$. The optical densities were measured at $450 \mathrm{~nm}$ in a microplate ELISA reader (LabSystems Multiskan Plus, LabX, Midland, ON, Canada). IFN- $\gamma$, IL-4, IL-17, IL-6, TNF- $\alpha$, IL-10 were measured in the serum with specific sandwich ELISA kits (PEPROTEC Inc., Cranbury, NJ, USA). according to the manufacturer's instructions.

\subsection{Measurements of NO in the Sera of Mice}

Briefly, sera were treated with ethanol (1:1) to precipitate proteins and other interfering factors. After centrifugation at $3000 \mathrm{rpm}$ for $20 \mathrm{~min}, 20 \mu \mathrm{L}$ of the recovered serum was placed into wells of an ELISA plate together with $100 \mu \mathrm{L}$ of the Griess reagent, and $80 \mu \mathrm{L}$ of distilled water. The Griess reagent is a volume-to-volume mixture of solution A ( $2 \%$ sulfanilamide in 5\% phosphoric acid) and solution B (0.1\% N-(1-naphthyl) ethylenediamine, dihydrochloride. After a $30 \mathrm{~min}$ incubation at $25^{\circ} \mathrm{C}$, the pink color developed was registered in an ELISA reader at $595 \mathrm{~nm}$. The values were extrapolated to a standard curve of sodium nitrite in the range $1-100 \mu \mathrm{M}$.

\subsection{Immunofluorescence}

Primary antibodies were obtained from the following companies: Goat anti-iNOS (clone M-19, Santa Cruz Biotechnology, Dallas, TX, USA), Rabbit anti-nitrotyrosine (AB 5411, EMD, Millipore, Burlington, MA, USA), biotin rat Ly6C/Ly6G (clone RB6-8C5, BD Pharmingen), goat anti-CD3 epsilon (Clone M-20, Santa Cruz Biotechnology), rat antimouse FoxP3 (clone FJK-16s, eBioscience, San Diego, CA, USA), goat anti-proliferating cell nuclear antigen (clone C-20, Santa Cruz Biotechnology), FITC-peanut agglutinin (L7381$1 \mathrm{MG}$, SIGMA, St. Louis, MO, USA), and APC-rat anti-mouse CD45R (clone RA3-6B2, BD Pharmingen).

Primary antibodies were revealed with the following secondary antibodies: Alexa Fluor 568 donkey anti-goat IgG (A11057, Thermo Fisher Scientific, Waltham, MA, USA), Alexa Fluor 488 donkey anti-rabbit IgG (711-546, Jackson ImmunoResearch Laboratories, West Grove, PA, USA), and Alexa Fluor 680 streptavidin (S32358, Thermo Fisher Scientific).

Five- $\mu \mathrm{m}$ formalin-fixed paraffinized sections were incubated at $60{ }^{\circ} \mathrm{C}$ overnight for deparaffinization. Tissue sections were quickly transferred to xylenes (247642-2.5L, SIGMA) and hydrated by sequentially immersing slides into absolute alcohol, $96 \%$ alcohol, 70\% alcohol, and water. Slides were immersed in an antigen retrieval solution, boiled for $30 \mathrm{~min}$, and cooled down for $10 \mathrm{~min}$ at room temperature (RT). Slides were rinsed several times in water and transferred to PBS. Non-specific binding was blocked with 5\% normal donkey serum in PBS containing $0.1 \%$ Tween 20 and $0.1 \%$ Triton-X-100, for $30 \mathrm{~min}$ at RT in a humid chamber. Primary antibodies were added to slides and incubated overnight in a moist chamber at RT. Slides were gently washed in PBS, and fluorescently labeled secondary antibodies were incubated for $2 \mathrm{~h}$, at RT, or overnight in a humid chamber. Finally, slides were rinsed for $1 \mathrm{~h}$ in PBS and mounted with Vectashield antifade mounting media with DAPI (H-1200, Vector Laboratories, Burlingame, CA, USA). Pictures were taken with a Zeiss Axioplan microscope. All germinal centers (GCs) in a lymph node section were measured with an automated tool of the Carl Zeiss microscope, and the average GC size was calculated using the Prism software. $\mathrm{CD}^{+}$FoxP3 $^{+}$Tregs were counted in 5 random $200 \times$ fields per tissue to calculate the average number of positive cells per field. 


\subsection{Statistical Analysis}

Statistically significant differences among groups were calculated by one-way ANOVA, Newman-Keuls multiple comparisons, unpaired/paired two-tailed Student's t-test, $p$ values $<0.05$ were considered to be statistically significant. Statistical differences were calculated with Graph Pad Prism.

\section{Results}

3.1. BCGphipps (BCGph)-Priming Followed by Successive Intramuscular hIFN- $\alpha 2 b$ Boosting Protects Balb/c Mice from Intradermal Challenge with M. lepraemurium

We previously developed a prime-boost protocol based on successive intramuscular boosting of IFN $\alpha$ after BCG vaccination of mice [42] with promising protection results. Recent studies used a BCG recombinant that expresses human IFN- $\alpha 2 b$ to treat bladder cancer $[51,53]$. Therefore, in the present study, our goal was to analyze the protection induced by BCGph priming followed by hIFN- $\alpha 2 \mathrm{~b}$ boosting in a murine model of leprosy, following the scheme depicted in Figure 1.

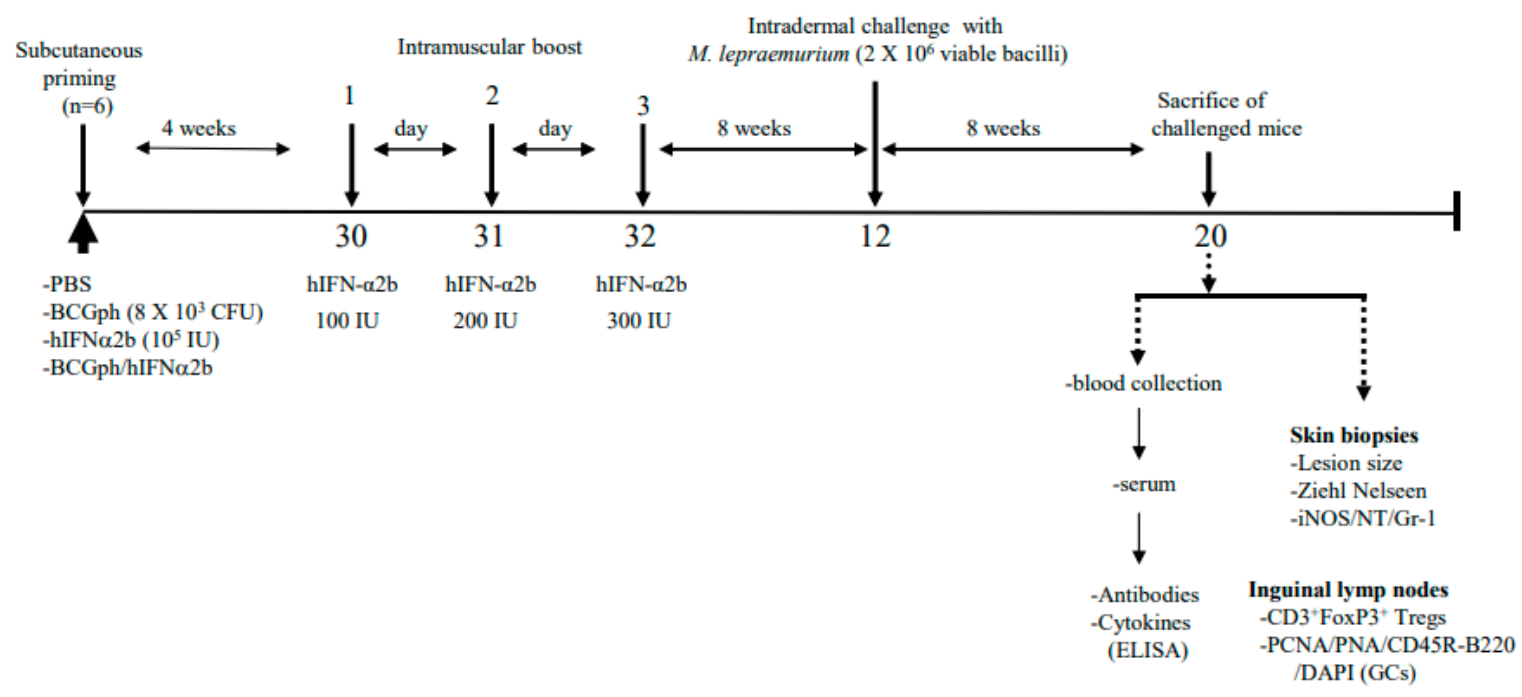

Figure 1. Prime-boost protocol to evaluate the protection of mice against intradermal challenge with M. lepraemurium. Groups of Balb/c mice $(n=6)$ were subcutaneously vaccinated with a low dose of BCGph $\left(8 \times 10^{3} \mathrm{CFU}\right)$. Mice from each group were intramuscularly boosted on consecutive days (30, 31, and 32 days after vaccination) with PBS or hIFN- $\alpha 2 b$. Mice were challenged with $2 \times 10^{6}$ viable MLM eight weeks after the last boosting. After that, mice were sacrificed, and biospecimens were collected eight weeks post-challenge. The development of skin lesions was monitored and measured as described in Material and Methods.

Briefly, mice were intradermally challenged with MLM, eight weeks after the third boost with $300 \mathrm{IU}$ of hIFN- $\alpha 2 \mathrm{~b}$. Disease progression was monitored during the next eight weeks. At the end of this period, we collected inguinal lymph nodes to detect GCs and enumerate Tregs and other cell populations by immunofluorescence. We also used immunofluorescence to visualize iNOS production by activated macrophages, location of nitrotyrosine (NT) residues, and accumulation of Gr-1+ myeloid cells in the skin of our experimental mice. Additionally, we collected the serum to measure the cytokines and antibodies to glycolipids of MLM by ELISA (Figure 1).

First, to evaluate the protective effect of BCGph priming and hIFN- $\alpha 2 b$ boosting against the intradermal challenge of mice with MLM, we measured the skin lesions and visualized bacilli colonization of the skin by the Ziehl-Neelsen stain (Figure 2A-E). The skin of unprimed mice that received only vehicle (PBS), without MLM challenge, showed no bacilli (Figure 2A). The mice inoculated with vehicle and challenged with MLM showed extensive amounts of MLM bacilli in the skin (Figure 2B), while priming mice with BCGph led to a reduction in the mycobacterial growth (Figure $2 \mathrm{C}$ ). Successive hIFN- $\alpha 2 \mathrm{~b}$ administration also reduced mycobacterial growth in the skin as compared with mice challenged 
with MLM (Figure 2D). The mice primed with BCGph and boosted with hIFN- $\alpha 2 b$ had the lowest mycobacterial growth (Figure 2E). Consistent with these data, the healthy mice challenged with MLM that received only vehicle (PBS) developed the most extensive skin lesions ( $35 \pm 9.9 \mathrm{~mm}^{2}$ ), while the mice that were BCGph-primed had skin lesions of similar size to the ones developed in the mice inoculated with the vehicle and challenged with MLM (13.5 $\pm 4.24 \mathrm{~mm}^{2}$ ) (Figure $\left.2 \mathrm{~F}\right)$. The mice subcutaneously injected with hIFN- $\alpha 2 \mathrm{~b}$ showed smaller skin lesions $\left(20 \pm 1.77 \mu \mathrm{m}^{2}\right)$. Of note, mice that were BCGph primed and boosted with hIFN- $\alpha 2 \mathrm{~b}$ showed a significant reduction in skin lesion size $\left(5 \pm 7.07 \mathrm{~mm}^{2}\right)$ $(p<0.05)$ (Figure 2F).

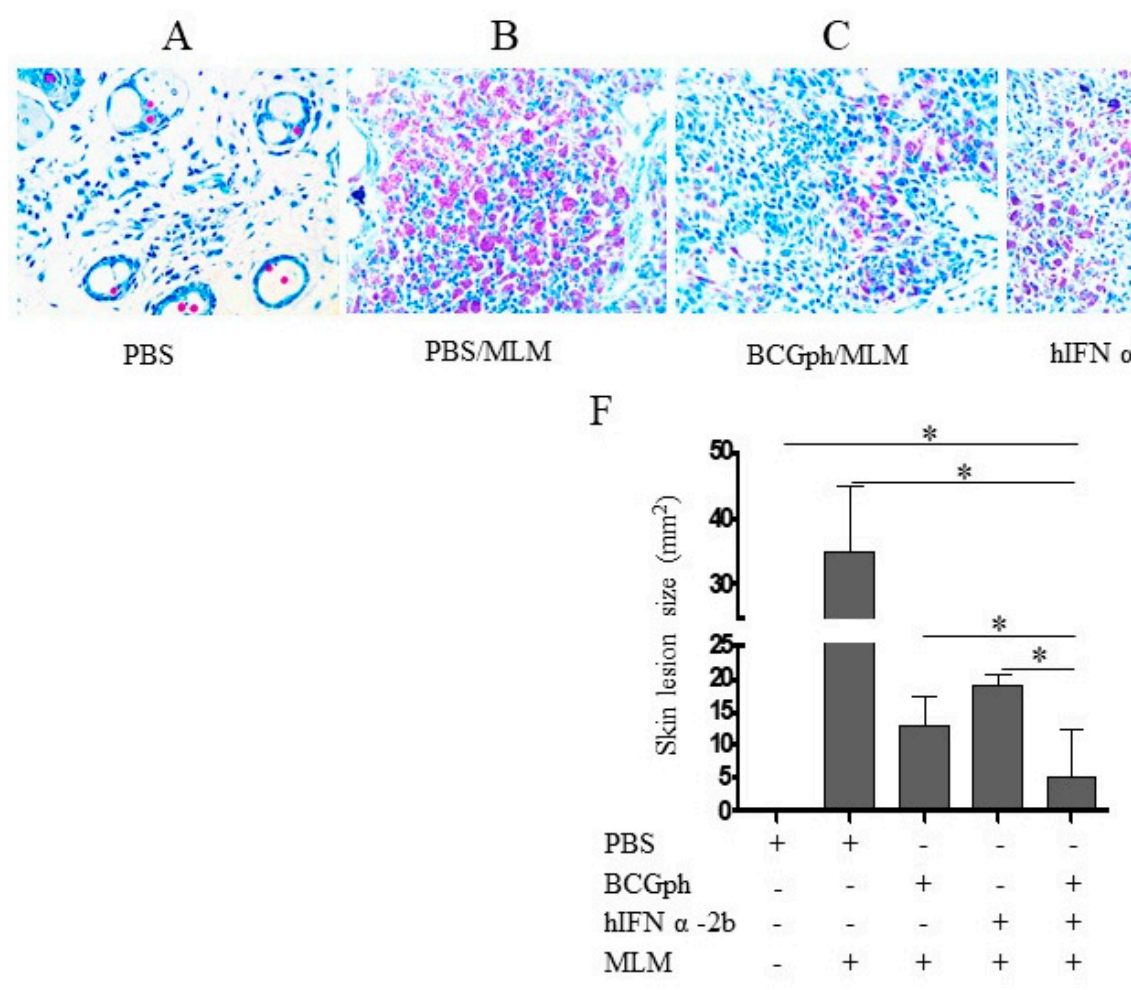

Figure 2. Skin lesions and mycobacterial growth in Balb/c challenged with M. lepraemurium. The protection of mice was assessed by skin lesion development and visualizing mycobacterial growth in the skin lesion at eight weeks post-challenge with MLM. Skin lesions were stained with Ziehl-Neelsen. Representative 400× magnifications pictures of (A) unprimed mice and unchallenged mice; (B) mice inoculated with PBS and challenged with MLM; (C) mice primed with BCGph and challenged with MLM; (D) mice intramuscularly inoculated with hIFN- $\alpha 2 \mathrm{~b}$ and challenged with MLM; (E) mice primed with BCGph, boosted with hIFN- $\alpha 2 b$, and challenged with MLM; (F) Efficient protection is equivalent to either the absence of skin lesions or a significant reduction in skin lesion size, expressed in $\mathrm{mm}^{2}, n=6$ mice/group. ${ }^{*} p<0.05 ;{ }^{* *} p<0.005$; *** $p<0.0005$ was considered to be statistically significant.

\subsection{Minimal Skin Pathology in Mice Primed with BCGphipps and Boosted with hIFN 2 2b Correlates with Decreased Nitrotyrosine Accumulation and Impaired Neutrophil Infiltration}

Nitric oxide is critical for the killing of intracellular pathogens. However, excessive production of nitric oxide, superoxide radical $\left(\mathrm{O}_{2}{ }^{-}\right.$, and hydrogen peroxide leads to the generation of toxic and unstable peroxynitrite, a molecule that reacts with tyrosine residues on proteins to form the stable NT [56-60]. Although peroxynitrite kills mycobacteria, it also damages immune cells [57-59]. Thus, we decided to search for iNOS producing cells, NT, and neutrophils in the skin of our experimental mice by immunofluorescence. We saw background signals for iNOS and NT and very few Gr-1 ${ }^{+}$cells in the skin of mice receiving only PBS (Figure 3A). Increased mycobacterial load and enlarged necrotic lesions in the skin correlated with the accumulation of NT residues in the necrotic skin area [58,59] of unvaccinated (Figure 3B) and BCGph primed mice challenged with MLM (Figure 3C). Consistent with a more balanced local inflammatory response and amelioration of skin 
pathology, NT and neutrophil infiltration were decreased in mice receiving successive inoculations with hIFN- $\alpha 2 b$ (Figure 3D) or mice BCGph primed and boosted with hIFN$\alpha 2 \mathrm{~b}$ (Figure 3E). Impaired infiltration with $\mathrm{Gr}-1^{+}$neutrophils and reduced NT areas coincided with the smallest inflammatory area in histological skin sections of mice primed with BCGph and boosted with hIFN- $\alpha 2 \mathrm{~b}$ (Figure 3F).

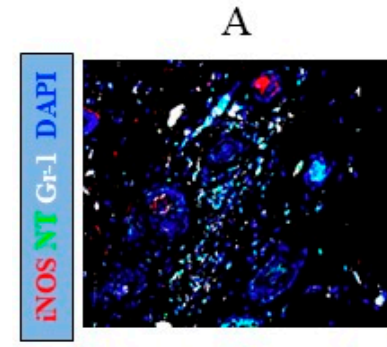

PBS
B

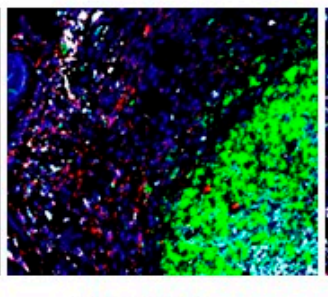

PBS/MLM
$\mathrm{C}$

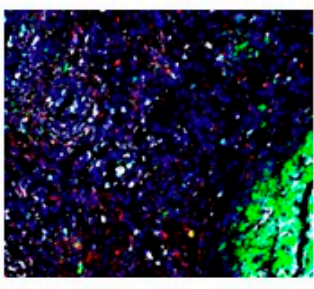

BCGph/MLM
$\mathrm{D}$

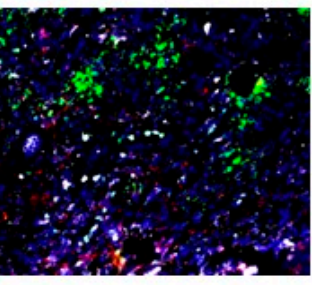

hIFN $\alpha .2 \mathrm{~b} / \mathrm{MLM}$
$\mathrm{E}$

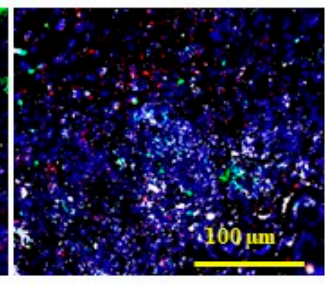

BCGph/hIFN- $\alpha 2 b$

$\mathrm{F}$

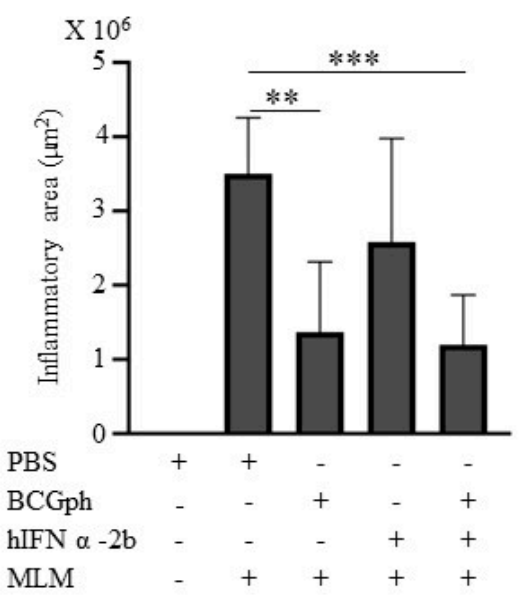

G

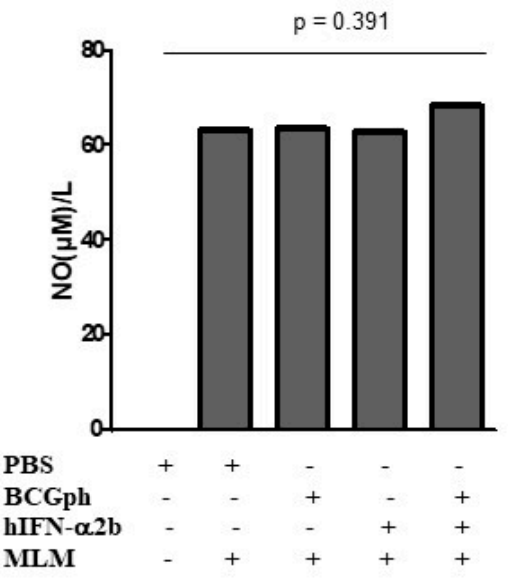

Figure 3. Protection associates with decreased nitrotyrosine accumulation, impaired neutrophil accumulation, and ameliorated skin inflammation. Skin lesion sections were stained with a combination of antibodies specific for iNOs (red), NT (green), Gr-1 (white). Representative $200 \times$ pictures from (A) Skin of unprimed and unchallenged mice, (B) mice inoculated with PBS and challenged with MLM, (C) mice primed with BCGphipps and challenged with MLM, (D) mice intramuscularly inoculated with hIFN- $\alpha 2 \mathrm{~b}$ and challenged with MLM and (E) mice primed with BCGph, boosted with hIFN- $\alpha 2 b$ and challenged with MLM; (F,G) quantitation of the inflammatory area with automated tools of Zeiss Axioplan microscope, skin lesions were collected at eight weeks post-challenge with MLM, graphics show the average area occupied by inflammatory cells in leprosy skin lesions, expressed in $\mu \mathrm{m}^{2}$. Scale bar $=100 \mu \mathrm{m} . n=6$ mice $/$ group $* p<0.05$; ${ }^{* *} p<0.005 ; * * * 0.0005$ was considered statistically significant.

NO production was not statistically significant compared to the other experimental groups however, in the group of mice BCGph-primed and boosted with hIFN- $\alpha 2 b$, the concentration of NO was higher $(68.28 \mu \mathrm{M} / \mathrm{L} \pm 0.889)$ than in the PBS and MLM groups $(62.79 \mu \mathrm{M} / \mathrm{L} \pm 1.04)$, BCGph $(63.37 \mu \mathrm{M} / \mathrm{L} \pm 0.225), \mathrm{hIFN}-\alpha 2 \mathrm{~b}(62.57 \mu \mathrm{M} / \mathrm{L} \pm 1.028)$ (Figure 3G).

\subsection{Anti-Inflammatory Cytokines Are Increased in the Serum of Mice Primed with BCGphipps and Boosted with hIFN- $\alpha 2 b$}

Pro- and anti-inflammatory cytokines were measured in the serum of Balb/c mice after challenge with MLM. Consistent with the immunosuppressive state caused by MLM, the concentrations of proinflammatory cytokines were low in the serum of Balb/c mice inoculated with PBS and challenged with MLM (IFN- $\gamma, 625 \pm 442 \mathrm{pg} / \mathrm{mL} ; \mathrm{TNF}-\alpha$, $697 \pm 436 \mathrm{pg} / \mathrm{mL}$; IL-6, $68 \pm 48 \mathrm{pg} / \mathrm{mL}$; IL-17, $95 \pm 67 \mathrm{pg} / \mathrm{mL})$. In contrast, they had moderate levels of anti-inflammatory cytokines in the serum (IL-10, $1763 \pm 124 \mathrm{pg} / \mathrm{mL}$ 
and IL-4, $1250 \pm 173 \mathrm{pg} / \mathrm{mL}$ ). Although mice were protected by BCGph priming and successive boosting with hIFN- $\alpha 2 b$, the systemic amounts of proinflammatory cytokines were not statistically different from those in mice inoculated with PBS and challenged with MLM. Unexpectedly, the concentration for IL-4 (1875 $\pm 352 \mathrm{pg} / \mathrm{mL}, p<0.05)$, and IL-10 $(4250 \pm 271 \mathrm{pg} / \mathrm{mL})$ were significantly increased in the serum of these mice as compared with mice inoculated with PBS and challenged with MLM (Table 1). These results suggest that our vaccination protocol might be activating anti-inflammatory pathways to prevent tissue damage.

Table 1. Serum cytokine profile in Balb/c mice intradermal challenge with Mycobacterium lepraemurium, after BCGphippspriming, and hIFN- $\alpha 2 b$ boosting.

\begin{tabular}{ccccccc}
\hline Experimental Groups & IFN- $\boldsymbol{\gamma}$ & IL-4 & IL-17 & TNF- $\gamma$ & IL-6 & IL-10 \\
\hline PBS BCGph & $625 \pm 442$ & $1250 \pm 173$ & $95 \pm 67$ & $697 \pm 436$ & $68 \pm 48$ & $1763 \pm 124$ \\
hIFN- $\alpha$ 2b S & $1641 \pm 154$ & $1437 \pm 108$ & $367 \pm 55$ & $784 \pm 62$ & $1065 \pm 60$ & $3201 \pm 214$ \\
BCGph/hIFN- $\alpha$ 2b S & $2086 \pm 609$ & $1637 \pm 53$ & $1230 \pm 0$ & $978 \pm 257$ & $1320 \pm 322$ & $2860 \pm 338$ \\
& $2062 \pm 299$ & $1875 \pm 352^{*}$ & $421 \pm 191$ & $859 \pm 122$ & $1270 \pm 26$ & $4250 \pm 271^{*}$ \\
\hline
\end{tabular}

BCGphipps (BCGph)-primed, IFN- $\alpha$ 2b boosted mice were sacrificed eight weeks after the challenge with Mycobacterium lepraemurium (MLM). Blood was collected to measure cytokines in serum by ELISA (PeproTech, Inc). Values are expressed as OD $450 \mathrm{~nm}$, represent the mean \pm SEM, standard error of the mean. Statistical significance was calculated with Newman Keuls Multiple comparisons test. ${ }^{*}, p<0.05$ was considered statistically significant.

\subsection{Impaired Treg Accumulation in the Draining Lymph Nodes (DLNs) of Mice Primed with BCGphipps or Boosted with hIFN- $\alpha 2 b$}

Considering that Tregs produce IL-10 [61,62], we decided to quantitate the CD3 ${ }^{+}$ $\mathrm{FOXP3}^{+}$Tregs in the draining lymph nodes (DLNs), located near the site of vaccination. In the uninfected mice (PBS), Tregs were still present $\left(113 \pm 9.8 \mathrm{CD3}^{+} \mathrm{FOXP3}^{+}\right.$Treg $/ 200 \times$ field) (Figure 4A). As expected, Tregs were significantly increased in mice challenged with MLM that did not receive the vaccine (BCGph) or hIFN- $\alpha 2 \mathrm{~b}\left(214 \pm 30 \mathrm{CD}^{+} \mathrm{FOXP}^{+}\right.$ Tregs $/ 200 \times$ field) (Figure 4B). Congruently, lower levels of Tregs were observed in the mice primed with BCGph $\left(160 \pm 26 \mathrm{CD}^{+} \mathrm{FOXP3}^{+}\right.$Tregs $/ 200 \times$ field $)($ Figure $4 \mathrm{C})$ and the mice that received hIFN- $\alpha 2 b\left(162 \pm 33 \mathrm{CD}^{+}\right.$FOXP3 $^{+}$Tregs $/ 200 \times$ field $)$ (Figure $\left.4 \mathrm{D}\right)$; the mice primed with BCGph and boosted with hIFN- $\alpha 2 \mathrm{~b}\left(127 \pm 16 \mathrm{CD}^{+}{ }^{\mathrm{FOXP3}^{+}}{ }^{+}\right.$Tregs $/ 200 \times$ field) (Figure $4 \mathrm{E}$ ) had a similar density of Tregs than unvaccinated mice without hIFN- $\alpha$ $2 \mathrm{~b}$ boosting. However, after blindly counting $\mathrm{CD}^{+} \mathrm{FOXP}^{+}$Tregs in the DLNs of our experimental mice, we found that Tregs were significantly reduced in the DLNs of mice after BCGph priming $(p=0.0013)$, hIFN- $\alpha 2 \mathrm{~b}$ inoculation $(p=0.0074)$, or combined BCGph priming and hIFN- $\alpha 2 \mathrm{~b}$ boosting $(p=0.0013)$ as compared with mice challenged with MLM (Figure 4E). 
A

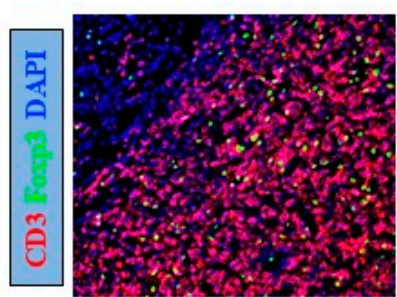

PBS
B

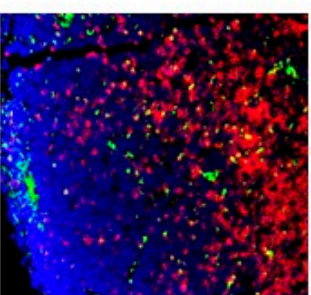

PBS/MLM
C

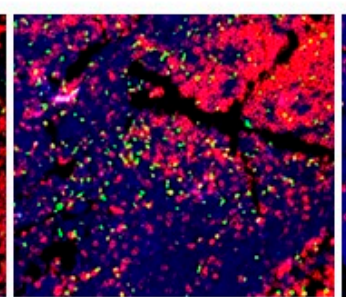

BCGph/MLM
D

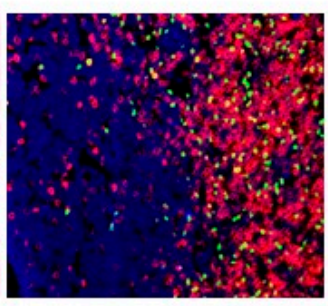

hIFN- $a$ 2b/MLM
E

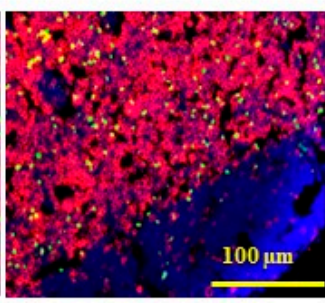

BCGph/hIFN- $\alpha 2 b$

F

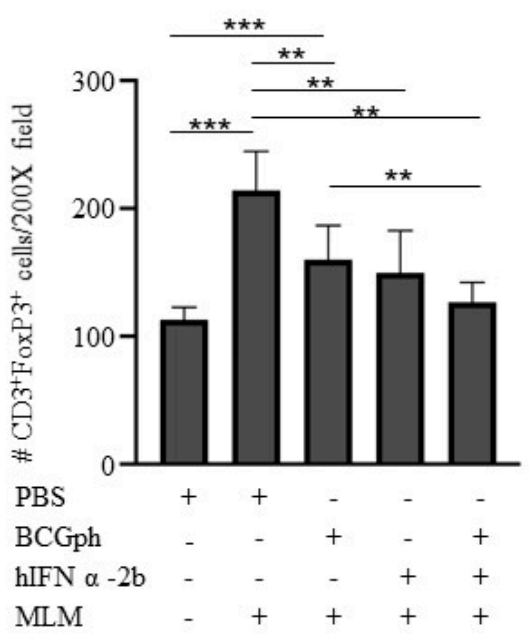

Figure 4. Impaired accumulation of regulatory T cells (Tregs) in the draining lymph nodes (DLNs) of mice primed with BCGphipps and boosted with hIFN- $\alpha 2 b$. Mice were sacrificed, and the DLNs were collected eight weeks post-challenge with MLM. DLN were stained with antibodies specific for $\mathrm{CD} 3$ (red) and FOXP3 (green nuclei) to detect $\mathrm{CD}^{+} \mathrm{FOXP}^{+}$ Tregs by immunofluorescence. (A) Basal accumulation of Tregs in the DLNs of unvaccinated mice; (B) Tregs in the DLNs were increased after MLM challenge and comparatively reduced in (C) BCGph-primed, (D) hIFN- $\alpha 2 \mathrm{~b}$ inoculated, and (E) BCGph-primed-hIFN- $\alpha 2 \mathrm{~b}$ boosted mice; (F) morphometric analysis shows a significant reduction in Tregs in the DLNs of BCGph primed/hIFN- $\alpha 2 \mathrm{~b}$ boosted mice. Scale bar $=100 \mu \mathrm{m}, n=6$ mice/group $* p<0.05$; ${ }^{* *} p<0.005 ; * * * p<0.0005$ was considered to be statistically significant.

\subsection{BCGphipps Priming and hIFN- $\alpha 2 b$ Boosting Influences GCs Responses in Mouse DLNs}

There are special Tregs located in the GCs known as T follicular regulatory cells (TFR). They modulate both the GCs responses and prevent the generation of autoreactive plasma cells $[28,33]$. The decreased Tregs in the DLNs suggested that GCs responses could be unleashed in mice primed with BCGph and boosted with hIFN- $\alpha 2 b$. Consistent with the absence of antigenic stimulation, we did not detect GCs in the DLNs of uninfected mice (Figure 5A). Small GCs were present in the DLNs of unprimed mice, challenged with MLM (Figure 5B). 
A

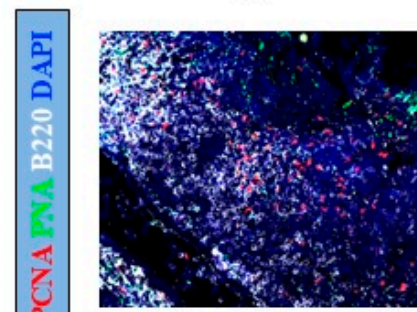

PBS
B

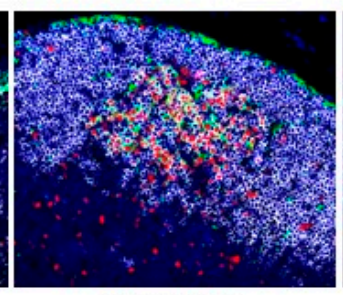

PBS/MLM
C

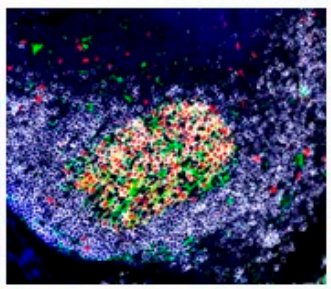

BCGph/MLM
D

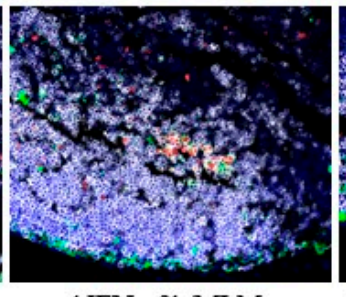

hIFN a.2b/MLM
E

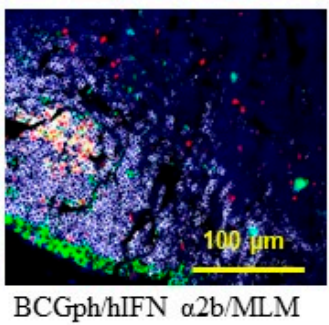

$\mathrm{F}$

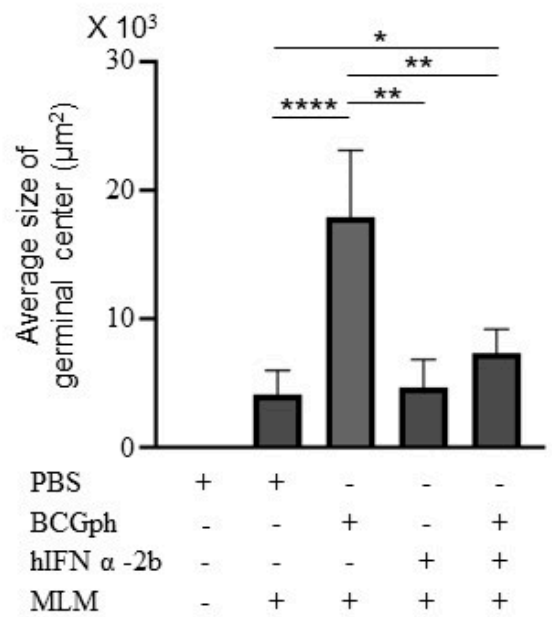

Figure 5. BCGphipps priming and hIFN- $\alpha 2$ b boosting influences GC responses in DLN after MLM challenge. Mice were sacrificed at eight weeks post-challenge with MLM. Draining lymph nodes (DLNs) were stained with antibodies specific for proliferating cell nuclear antigen (PCNA, red nuclei), peanut agglutinin (PNA, green), and CD45R (B220, white) to identify GCs containing compact clusters of PCNA ${ }^{+} \mathrm{PNA}^{++} \mathrm{B} 220^{\mathrm{low}}$ GC B cells. GC B cells in DLNs of (A) unprimed and unchallenged mice; (B) mice inoculated with PBS and challenged with MLM; (C) mice primed with BCGph and challenged with MLM; (D) mice intramuscularly boosted with hIFN- $\alpha 2 b$ and challenged with MLM; (E) mice primed with BCGph, boosted with hIFN- $\alpha 2 b$, and challenged with MLM; (F) GC were measured in individual DLNs of experimental mice to calculate the average GC size. Scale bar $=100 \mu \mathrm{m} . n=6$ mice/group. ${ }^{*} p<0.05 ;{ }^{* *} p<0.005 ;{ }^{* * *} p<0.0005$ was considered to be statistically significant.

Interestingly, mice primed with BCGph had significantly larger GCs than mice challenged with MLM (Figure 5C). The mice immunized with hIFN- $\alpha 2 b$ (Figure 5D) had GCs with a comparable size to those in mice challenged with MLM. The mice primed with BCGph and boosted with hIFN- $\alpha 2 b$ had GCs with an intermediate size (Figure 5E). To have a more quantitative assessment of the GCs responses in the DLNs, we calculated the average GC size in individual DLN sections. Consistent with our observations, we found a significant reduction in the average GC size in the DLNs after hIFN- $\alpha 2 b$ injection and in the BCGph priming/hIFN- $\alpha 2 \mathrm{~b}$ boosting protocol (Figure $5 \mathrm{E}$ ).

\subsection{Comparable Levels of Glycolipid-Specific Antibodies in Mice Challenged with M.} lepraemurium after BCGphipps Priming and hIFN- $\alpha 2 b$ Boosting

According to the differences observed in GC formation and organization, we measured the concentration of antibodies specific for glycolipids extracted from MLM. Globally, our results show that the systemic amounts of different classes and isotypes of glycolipidspecific antibodies were not affected by vaccination, successive administration of hIFN- $\alpha 2 b$, or the BCGph priming/hIFN- $\alpha 2 b$ protocol (Table 2 ). Mice boosted only with hIFN- $\alpha 2 b$ elicited a higher amount of IgG and IgG1 antibodies in the serum. However, IgG and Ig G1 antibody levels were not statistically significant as compared with the other experimental groups (Table 2). 
Table 2. Serum Glycolipid-Specific antiboides in Balb/c mice intradermal challenge with Mycobacterium lepraemurium after BCGphipps-priming, and hIFN- $\alpha 2$ b boosting.

\begin{tabular}{ccccccc}
\hline Experimental Groups & IgM & IgG & IgG1 & IgG2a & IgG2b & IgG3 \\
\hline PBS & $0.86 \pm 0.30$ & $1.05 \pm 0.07$ & $1.70 \pm 0.0$ & $1.25 \pm 0.21$ & $1.35 \pm 0.07$ & $0.89 \pm 0.03$ \\
BCGph & $0.99 \pm 0.15$ & $1.10 \pm 0.33$ & $1.10 \pm 0.41$ & $1.40 \pm 0.32$ & $1.30 \pm 0.30$ & $0.90 \pm 0.28$ \\
hIFN- $\alpha$ 2b S & $1.00 \pm 0.27$ & $1.40 \pm 0.13$ & $1.80 \pm 0.11$ & $1.56 \pm 0.38$ & $1.30 \pm 0.08$ & $1.10 \pm 0.10$ \\
BCGph-hIFN- $\alpha$ 2b S & $0.90 \pm 0.07$ & $1.05 \pm 0.28$ & $1.50 \pm 0.21$ & $1.40 \pm 0.06$ & $1.30 \pm 0.19$ & $0.93 \pm 0.04$ \\
\hline
\end{tabular}

-BCGphipps (BCGph)-primed, and IFN- $\alpha 2 \mathrm{~b}$ boosted mice were sacrificed eight weeks after the challenge with Mycobacterium lepraemurium (MLM). Blood was collected to measure anti-glycolipid-1 specific antibodies by ELISA. Values are expressed as OD ${ }_{450} \mathrm{~nm}$ and represent the mean \pm SEM, standard error of the mean. Not statistical significance was found at ${ }^{*}, p<0.05$ calculated with Newman Keuls Multiple comparisons test.

\section{Discussion}

In the present study, we have shown that our prime-boosting protocol based on subcutaneous BCGphipps priming and successive intramuscular boosting with increasing amounts of hIFN- $\alpha 2 \mathrm{~b}$ protected mice from intradermal challenge with MLM.

The prime-boosting protocol prevented MLM growth in the skin and ameliorated local pathology by decreasing NT production and neutrophilic inflammation (Figure 3E). It also resulted in the induction of anti-inflammatory cytokines (IL-4 and IL-10) that likely counteracted excessive inflammation in the skin and manifested systemically. Unexpectedly, although the therapeutic regimen decreased $\mathrm{CD}^{+} \mathrm{FOXP3}^{+}$Tregs in the DLNs (Figure 4E), GC responses were not drastically enhanced (Figure 5E), and the serum concentrations of glycolipid-specific antibodies were similar in all the experimental groups except in the mice inoculated only with hIFN- $\alpha 2 b$ (Table 2). Nevertheless, our experimental data support the potential use of BCG priming adjuvanted with intramuscular IFN $\alpha 2 b$ boosting, as a promising immunotherapy that deserves exploration in human leprosy.

The clinical manifestations of leprosy correlate with the immunological spectrum detected in patients and range from LL to TT $[2,4,14,18]$. In general, host immunity to $M$. leprae is characterized mainly by a polarized T helper response (Th1/Th2). On one side of the spectrum, although LL is characterized by anergy, there is still some reactivity to mycobacterial antigens and the production of IL-4 and IL-10. In contrast, in TT, a predominant Th1 response leads to the IFN- $\gamma$ driven activation of macrophages, which accelerates the elimination of the bacilli. Mice infected with MLM typically develop lepromatous-like leprosy without a clear dominance for humoral or cellular immunity [18-20].

Protective antibodies elicited by infection or vaccination [63] are produced by a process called affinity maturation, which takes place in germinal centers formed in secondary (spleen, lymph nodes) or tertiary lymphoid organs (TLO) generated in peripheral tissues $[23,25]$. It is precisely in the GCs where the production of memory B cells and long-lived antibody-secreting plasma cells contribute to the generation of long-term immunity to future encounters with pathogens. The efficient induction of GC responses depends on the collaboration of multiple cell types, including B cells, T follicular helper cells (TFH), tingible body macrophages, and follicular dendritic cells (FDCs) [64]. Indeed, vaccines trigger successful GC responses, and ectopic germinal centers in lymph nodes [24,25,31,49]. Moreover, $\mathrm{T}$ follicular helper cells and T follicular regulatory cells [27-30] maintain the delicate balance between the induction of effective antibody responses and autoimmunity. Although we did not rule out autoimmunity induction in our study, we still focused on the effects of the prime-boost protocol with BCGph and hIFN- $\alpha 2 b$ on the Tregs from the DLNs. Protected mice had significantly fewer $\mathrm{CD}^{+} \mathrm{FOXP3}^{+}$Tregs in their DLNs. However, further studies are required to determine if some of these Tregs are $\mathrm{T}$ follicular helper cells that regulate GC reactions [27-30]. These results might imply that efficient induction of protective immunity combined with a slight decrease of Tregs in the DLNs is required to control mycobacterial growth and to prevent pathologic inflammation in the skin.

Previous studies have reported the systemic and mucosal effects of type I IFN on T follicular helper cells and T follicular regulatory cells $[19,32,64]$. Indeed, type I IFN indirectly 
increases TFH in lymph nodes by stimulating T cell priming by dendritic cells [34]. Type I IFN also promotes isotype switch in GCs. In addition, a recent study showed that type I IFN triggers the CXCL13-driven formation of TLO in the lungs [49]. Thus, the induction of CXCL13 by type I IFN could enhance the recruitment of naïve B cells to secondary lymphoid organs and increase the production of antibody-secreting plasma cells, globally improving long-lasting memory and plasma cells immunological responses [23-25,64], particularly in the presence of adjuvants like poly IC [65]. In addition, type I IFN administration induces GC formation in the lungs of patients afflicted by autoimmune diseases [31] or tuberculosis $[66,67]$. Thus, CXCL13 blockade could help treat these chronic inflammatory disorders [49]. In this context, we observed a very mild decrease in the GC size in DLNs of protected prime-boosted mice (Figure 5E). However, additional research is needed to better define the correlation between GC formation and the protection induced in those prime-boosted mice. Under the experimental settings of priming with BCGph and intramuscular hIFN- $\alpha 2 b$ boosting (51), the mice in our study experienced higher protection by the BCGph-hIFN- $\alpha 2 \mathrm{~b}(80 \%)$ administration than by BCGph alone $(60 \%)$, as determined by the absence or the small size of the skin lesions (Figure 2) and a comparable quantity of IgG and IgG1 antibodies specific for glycolipids of MLM (Table 2). Our results contrast with the increased amount of IgG in mice protected by vaccination with a different strain of BCG (Pasteur) [41]. These data suggest that the type of BCG strain used to formulate the vaccine could influence the outcome of the humoral immune response against MLM or M. leprae [51]. Furthermore, several studies in tuberculosis have shown the potential and beneficial effects of the heterologous prime-boost strategy in the induction of protective immune responses [68-70]. Moreover, it is well known that the type and the route of immunization influence the magnitude of the antibody and cellular immune responses. Surprisingly, protected mice show significantly higher IL-4 and IL-10 in the serum as compared with mice treated only with PBS, BCGph, or hIFN- $\alpha 2 b$ alone (Table 1). How anti-inflammatory cytokines influence protective immunity in leprosy is currently under investigation in our laboratory. However, several studies have shown that efficient cellular immunity to mycobacteria relies on a delicate balance between protection and prevention of pathology [71]. In addition, there is evidence of induction of both cytokine types in other experimental models [72-75].

Our collective results suggest that the success of our prime-boost protocol depends on the induction of a balanced immune response that efficiently eliminates MLM in the skin and limits tissue damage by inducing anti-inflammatory cytokines (IL- 4 and IL10) that likely protect immune cells [76,77]. Indeed, IL-10 produced by induced Tregs modulates inflammation at mucosal surfaces, specifically those related to inflammatory bowel disease $[77,78]$. These findings warrant a detailed kinetic study of $\mathrm{B}$ cell activation, $\mathrm{GC}$ formation and regulation, $\mathrm{T}$ follicular regulatory cells cells generation, and NF- $\mathrm{kB}$ activation in our prime-boost system with BCGph and hIFN- $\alpha 2 b$ followed by MLM infection to have a more mechanistic understanding of the roles of immune cells and NF- $\mathrm{kB}$ pathways in the induction of protective immunity in the skin and lymph nodes after MLM challenge.

\section{Conclusions}

From these data, we can conclude that the successive intramuscular boosting with hIFN- $\alpha 2 \mathrm{~b}$ enhances $M$. bovis BCG vaccination, protecting against intradermal challenge with MLM and revealing the promising adjuvant properties of human IFN-a $2 b$ in the context of BCG vaccination for preventing leprosy infections in endemic areas. To the best of our knowledge, this is the first report of the therapeutic efficacy of BCGphipps in combination with a pharmaceutical presentation of hIFN- $\alpha 2 b$ in a preclinical model of leprosy-like disease.

Author Contributions: Study design, G.G.G., O.R.-E., S.O.I.-T. and J.R.-M.; study conduct, G.G.G., O.R.-E., S.O.I.-T. and J.R.-M.; data analysis: G.G.G., O.R.-E., S.O.I.-T. and J.R.-M.; data interpretation, G.G.G., O.R.-E., S.O.I.-T. and J.R.-M.; drafting manuscript, G.G.G., O.R.-E., S.O.I.-T. and J.R.-M.; 
revising manuscript content, G.G.G., O.R.-E., S.O.I.-T. and J.R.-M.; G.G.G., O.R.-E., S.O.I.-T. and J.R.-M. take responsibility for the integrity of the data analysis. All authors have read and agreed to the published version of the manuscript.

Funding: G.G.G. and O.R.-E. were supported by SNI, CONACYT (Mexico City, Mexico). G.G.G. received support from Perfil Prodep 2019-2022, and J.R.-M. was supported by internal funds from the Department of Medicine University of Rochester Medical Center and RO1AI111914.

Institutional Review Board Statement: All animal experiments were performed after approval by the Institutional Animal Care and Management Committee (ZOO-010-2020). CIE-ENCB ZOO 016/2014, 07 March 2014.

Informed Consent Statement: Not applicable.

Data Availability Statement: Data will be shared following institutional guidelines.

Acknowledgments: We are grateful to Ricardo Villalobos for help with IHC, and Rogelio Hernandez Pando (INCMNSZ, Mexico City), who provided the BCGphipps strain.

Conflicts of Interest: The authors declare no conflict of interest.

\section{References}

1. WHO. World Health Organization: Tuberculosis—Global Facts 2011/2102. Geneva: WHO Stop TB Dep. 2012. Available online: http:/ / www.who.int/tb/publications/2011/factsheet_tb_2011.pdf (accessed on 1 February 2021).

2. Fine, P.E. Leprosy: What is being "eliminated"? Bull. World Health Organ. 2007, 85, 1-2. [CrossRef]

3. Rambukkana, A. How does Mycobacterium leprae target the peripheral nervous system? Trends Microbiol. 2000, 8, 23-28. [CrossRef]

4. Rodriguez, J.I.A.; Triellato, G.L.; Meirelles, N.M.L.; Teixeira, C.C.; Lyon, S.; Esteves, A.R.M. Leprosy classification methods: A comparative study in a referral character in Brazil. Int. J. Infect. Dis. 2016, 45, 118-122. [CrossRef] [PubMed]

5. Geluk, A.; van der Ploeg, J.; Teles, O.B.R.; Kees, L.; Franken, M.C.; Prins, C.; Wouter, D.J.; Sarno, N.E.; Sampaio, E.P.; Otenhoff, T.H.M. Rational combination of peptides derived from different Mycobacterium leprae proteins improves sensitivity for immunodiagnosis of M. leprae infection. Clin. Vacc. Immunol. 2008, 15, 522-533. [CrossRef] [PubMed]

6. Geluk, A.; Bobosha, K.; Schip, J.J.V.D.P.-V.; Spencer, J.S.; Banu, S.; Martins, M.V.S.B.; Cho, S.N.; Franken, K.L.M.C.; Kim, H.J.; Bekele, Y.; et al. New Biomarkers with Relevance to Leprosy Diagnosis Applicable in Areas Hyperendemic for Leprosy. J. Immunol. 2012, 188, 4782-4791. [CrossRef]

7. Geluk, A. Biomarkers for Leprosy: Would you prefer T (cells)? Lepr. Rev. 2013, 84, 3-12. [CrossRef] [PubMed]

8. Alcaïs, A.; Alter, A.; Antoni, G.; Orlova, M.; Nguyen, V.T.; Singh, M.; Vanderborght, P.R.; Katoch, K.; Mira, M.T.; Vu, H.T.; et al. Stepwise replication identifies a low-producing lymphotoxin- $\alpha$ allele as a major risk factor for early-onset leprosy. Nat. Genet. 2007, 39, 517-522. [CrossRef] [PubMed]

9. Avanzi, C.; Singh, P.; Truman, R.W.; Suffys, P.N. Molecular epidemiology of leprosy: An update. Infect. Genet. Evol. 2020, 86, 104581. [CrossRef]

10. Lastoria, J.C.; Abreu, M.A. Leprosy review of the epidemiological clinical and ethnopathogenic aspects-part 1. Bras. Dermatol. 2014, 89, 205-218. [CrossRef]

11. Rojas-Espinosa, O. Current Topics on the Profiles of Host Immunological Response to Mycobacterial Infections; Review Book; Tomioka, H., Ed.; Research Signpost: Trivandrum, India, 2009; pp. 97-140.

12. Adams, L.B.; Pena, T.M.; Sharma, R.; Hagge, A.D.; Schurr, E.; Truman, R.W. Insights from animal models on the immunogenetics of leprosy. A Review. Mem. Inst. Oswaldo. Cruz. 2012, 107, 197-208. [CrossRef]

13. Rojas-Espinosa, O.; Becerril-Villanueva, E.; Wek-Rodriguez, K.; Arce-Paredes, P.; Reyes-Maldonado, E. Palsy of the rear limbs in Mycobacterium lepraemurium-infected mice results from bone damage and not from nerve involvement. Clin. Exp. Immunol. 2005, 140, 436-442. [CrossRef]

14. Modlin, L.R. The innate immune response in leprosy. Curr. Opin. Immunol. 2010, 22, 48-54. [CrossRef]

15. Oliveira, R.B.; Ochoa, M.T.; Sieling, P.A.; Rea, T.H.; Rambukkana, A.; Sarno, E.N.; Modlin, R.L. Expression of Toll-Like Receptor 2 on Human Schwann Cells: A Mechanism of Nerve Damage in Leprosy. Infect. Immun. 2003, 71, 1427-1433. [CrossRef]

16. MacMicking, J.; Xie, Q.W.; Nathan, C. Nitric oxide and macrophage function. Annu. Rev. Immunol. 1997, 15, 323-350. [CrossRef]

17. Evans, T.; Buttery, L.; Carpenter, A.; Springall, D.R.; Polak, J.; Cohen, J. Cytokine-Treated Human Neutrophils Contain Inducible Nitric Oxide Synthase That Produces Nitration of Ingested Bacteria. Proc. Natl. Acad. Sci. USA 1996, 93, 9553-9554. [CrossRef] [PubMed]

18. Fonseca, A.B.; Simon, M.D.; Cazzaniga, R.A.; de Moura, T.R.; de Almeida, R.P.; Duthie, M.S.; Reed, S.G.; de Jesus, A.R. The influence of innate and adaptative immune responses on the differential clinical outcomes of leprosy. Infect. Dis. Poverty 2017, 6, 5-13. [CrossRef] [PubMed]

19. Sadhu, S.; Khaitan, B.K.; Joshi, B.; Sengupta, U.; Nautiyal, A.K.; Mitra, D.K. Reciprocity between Regulatory T Cells and Th17 Cells: Relevance to Polarized Immunity in Leprosy. PLoS Negl. Trop. Dis. 2016, 10, e0004338. [CrossRef] [PubMed] 
20. Rojas-Espinosa, O.; Wek-Rodríguez, K.; Arce-Paredes, P. The effect of exogenous peroxidase on the evolution of murine leprosy. Int. J. Lepr. Other Mycobact. Dis. 2002, 70, 191-200.

21. Ischiropoulos, H. Biological Tyrosine Nitration: A Pathophysiological Function of Nitric Oxide and Reactive Oxygen Species. Arch. Biochem. Biophys. 1998, 356, 1-11. [CrossRef]

22. Young, D.B. Leprosy lipid provides the key to Schwann cell entry. Trends Microbiol. 2001, 9, 52-54. [CrossRef]

23. Bannard, O.; Cyster, J.G. Germinal centers: Programmed for affinity maturation and antibody diversification. Curr. Opin. Immunol. 2017, 45, 21-30. [CrossRef] [PubMed]

24. Victora, D.G.; Nussenweig, M.C. Germinal centers. Annu. Rev. Immunol. 2012, 30, 429-457. [CrossRef] [PubMed]

25. Cirelli, K.M.; Crotty, S.H. Germinal center enhancement by extended antigen availability. Curr. Opin. Immunol. 2017, 47, 64-69. [CrossRef]

26. Good-Jacobson, K.L.; Szumilas, C.G.; Chen, L.; Sharpe, A.H.; Tomayko, M.M.; Shlomchik, M.J. PD-1 regulates germinal center B cell survival and the formation and affinity of long-lived plasma cells. Nat. Immunol. 2010, 11, 535-542. [CrossRef]

27. Wollenberg, I.; Agua-Doce, A.; Hernández, A.; Almeida, C.; Oliveira, V.G.; Faro, J.; Graca, L. Regulation of the Germinal Center Reaction by Foxp3+ Follicular Regulatory T Cells. J. Immunol. 2011, 187, 4553-4560. [CrossRef] [PubMed]

28. Litterman, M.A.; Piersone, W.; Lee, S.K.; Kallies, A.; Kawamot, S.; Rayner, T.F.; Srivastava, M.; Divekar, D.P.; Beaton, L.; Hogan, J.J.; et al. FOXP3+ follicular regulatory T cells control the germinal center response. Nat. Med. 2011, 17, 975-982. [CrossRef]

29. Miles, B.; Connick, E. Control of the Germinal Center by Follicular Regulatory T Cells During Infection. Front. Immunol. 2018, 9 , 2704-3710. [CrossRef]

30. Fu, W.; Liu, X.; Lin, X.; Feng, H.; Sun, L.; Li, S.; Chen, H.; Tang, H.; Lu, L.; Jin, W.; et al. Deficiency in T follicular regulatory cells promotes autoimmunity. J. Exp. Med. 2018, 215, 815-825. [CrossRef]

31. Pitzalis, C.; Jones, G.W.; Bombardieri, M.; Jones, S.A. Ectopic lymphoid-like structures in infection, cancer and autoimmunity. Nat. Rev. Immunol. 2014, 14, 447-462. [CrossRef]

32. Aloulou, M.; Carr, E.J.; Gador, M.; Bignon, A.; Liblau, R.S.; Fazilleau, N.; Linterman, M.A. Follicular regulatory T cells can be specific for the immunizing antigen and derive from naive T cells. Nat. Commun. 2016, 7, 10579-10589. [CrossRef]

33. Vinuesa, C.G.; Sanz, I.; Cook, M.C. Dysregulation of germinal centers in autoimmune disease. Nat. Rev. Immunol. 2009, 9, 845-857. [CrossRef]

34. Cucak, H.; Yrlid, U.; Reizis, B.; Kalinke, U.; Johansson-Lindborn, B. Type I Interferon signaling in Dendritic cells stimulates the development of Lymph Node-Resident T follicular helper cells. Immunity 2009, 31, 491-501. [CrossRef]

35. Desvignes, L.; Wolf, A.J.; Ernst, J.D. Dynamic Roles of Type I and Type II IFNs in Early Infection with Mycobacterium tuberculosis. J. Immunol. 2012, 188, 6205-6215. [CrossRef]

36. Teles, M.B.R.; Graeber, G.T.; Krutzik, R.S.; Montoya, D.; Schenk, M.; Lee, J.D.; Komisopoulou, E.; Kelly-Scumpia, K.; Chun, R.; Iyer, S.S.; et al. Type I Interferon suppresses Type II Interferon-Triggered human Anti-Mycobacterial Responses. Science 2013, 339, 1448-1453. [CrossRef]

37. Ji, D.X.; Yamashiro, L.H.; Chen, K.J.; Mukaida, N.; Kramnik, I.; Darwin, K.H.; Vance, R.E. Type I interferon-driven susceptibility to Mycobacterium tuberculosis is mediated by IL-1Ra. Nat. Microbiol. 2019, 4, 2128-2135. [CrossRef]

38. Manca, C.; Tsenova, L.; Bergtold, A.; Freeman, S.H.; Tovey, M.; Musser, M.J.; Barry, E.C., 3rd; Freedman, H.V.; Kaplan, G. Virulence of a Mycobacterium tuberculosis clinical isolate in mice is determined by failure to induce Th1 type immunity and is associated with induction of IFN- $\alpha / \beta$. Proc. Natl. Acad. Sci. USA 2007, 98, 5752-5757. [CrossRef] [PubMed]

39. Telesca, C.; Angelico, M.; Piccolo, P.; Nosotti, L.; Morrone, A.; Longhi, C.; Carbone, M.; Baiocchi, L. Interferon-alpha treatment of hepatitis D induces tuberculosis exacerbation in an immigrant. J. Infect. 2007, 54, e223-e226. [CrossRef] [PubMed]

40. Giacomini, E.; Remoli, M.E.; Gafa, V.; Pardini, M.; Fattorini, L.; Coccia, E.M. IFN- $\beta$ improves BCG immunogenicity by acting on DC maturation. J. Leukoc. Biol. 2008, 85, 462-468. [CrossRef] [PubMed]

41. Rivas-Santiago, C.E.; Guerrero, G.G. IFN- $\alpha$ Boosting of Mycobacterium bovis Bacillus Calmette Güerin-Vaccine Promoted Th1 Type Cellular Response and Protection against M. tuberculosis Infection. BioMed Res. Int. 2017, 2017, 6760. [CrossRef]

42. Guerrero, G.G.; Rangel-Moreno, J.; Islas-Trujillo, S.; Rojas-Espinosa, O. Successive Intramuscular Boosting with IFN-Alpha Protects Mycobacterium bovis BCG-Vaccinated Mice against M. lepraemurium infection. BioMed Med. Res. Int. 2015, $2015,414027$.

43. McNab, F.; Mayer-Barber, K.; Sher, A.; Wack, A.; O'Garra, A. Type I interferon in infectious disease. Nat. Rev. Immunol. 2015, 15, 67-103. [CrossRef]

44. O'Shea, J.J.; Visconti, R. Type I IFNs and regulation of TH1 responses: Enigmas both resolved and emerged. Nat. Immunol. 2000, 1, 17-19. [CrossRef]

45. González-Navajas, J.M.; Lee, J.; David, M.; Raz, E. Immunomodulatory functions of type I interferons. Nat. Rev. Immunol. 2012, 12, 125-135. [CrossRef]

46. Le Bon, A.; Tough, D.F. Type I interferon as a stimulus for cross-priming. Cytokine Growth Fact Rev. 2008, 19, 33-40. [CrossRef]

47. Bracci, L.; Canini, I.; Puzelli, S.; Sestili, P.; Venditti, M.; Spada, M.; Donatelli, I.; Belardelli, F.; Proietti, E. Type I IFN is a powerful mucosal adjuvant for a selective intranasal vaccination against influenza virus in mice and affects antigen capture at mucosal level. Vaccine 2005, 23, 2994-3004. [CrossRef]

48. Couch, R.B.; Atmar, R.L.; Cate, T.R.; Quarles, J.M.; Keitel, W.A.; Arden, N.H.; Wells, J.; Niño, D.; Wyde, P.R. Contrasting effects of type I interferon as a mucosal adjuvant for influenza vaccine in mice and humans. Vaccine 2009, 27, 5344-5348. [CrossRef] [PubMed] 
49. Denton, A.E.; Innocentin, S.; Carr, E.J.; Bradford, B.M.; Lafouresse, F.; Mabbott, N.A.; Mörbe, U.; Ludewig, B.; Groom, J.R.; Good-Jacobson, K.L.; et al. Type I interferon induces CXCL13 to support ectopic germinal center formation. J. Exp. Med. 2019, 216, 621-637. [CrossRef]

50. Toledo, P.T.G.; Batista-Silva, L.R.; Medeiros, R.C.A.; Lara, F.A.; Moraes, M.O. Type I Interferons, Autophagy and Host Metabolism in Leprosy. Front. Immunol. 2018, 23, 806-817. [CrossRef]

51. Zhang, W.; Zhang, Y.; Zheng, H.; Pan, Y.; Liu, H.; Du, P.; Wan, L.; Liu, J.; Zhu, B.; Zhag, G.; et al. Genome sequencing and analysis of BCG vaccine strains. PLoS ONE 2013, 8, e071243. [CrossRef]

52. Wek-Rodriguez, K.; Silva-Miranda, M.; Arce-Paredes, P.; Rojas-Espinosa, O. Effect of reactive oxygen intermediaries on the viability and infectivity of Mycobacterium lepraemurium. Int. J. Exp. Pathol. 2007, 88, 137-145. [CrossRef]

53. Kim, S.H.; Cohen, B.; Novick, D.; Rubinstein, M. Mammalian Type I Interferon Receptors Consists of Two Subunits: IFN- $\alpha$ R1 and IFN- $\alpha$ R2. Gene 1997, 196, 279-286. [CrossRef]

54. Luo, Y.; Chen, X.; Han, R.A.; O’Donnell, M. Recombinant bacille Calmette-Guérin (BCG) expressing human interferon-alpha 2B demonstrates enhanced immunogenicity. Clin. Exp. Immunol. 2001, 123, 264-270. [CrossRef] [PubMed]

55. Sun, E.; Nian, X.; Liu, C.; Fan, X.; Han, R. Construction of recombinant human IFN $\alpha-2 b$ BCG and its antitumor effects on bladder cancer cells in vitro. Genet. Mol. Res. 2015, 14, 3436-3449. [CrossRef] [PubMed]

56. Prabhakaran, K.; Harris, E.B.; Kirchheimer, W.F. Binding of 14C-labeled dopa by Mycobacterium leprae in vitro. Int. J. Lepr. Other Mycobact. Dis. 1976, 44, 58-64.

57. Draper, P. Purification of Mycobacterium leprae. In Proceedings of the Annex 4 of Report of the Fifth Meeting of the Scientific Working Group on the Immunology of Leprosy (IMMLEP), Geneva, Switzerland, 24-26 June 1980; World Health Organization: Geneva, Switzerland, 1980.

58. Ischiropoulos, H.; Nelson, J.; Duran, D.; Al-Mehdi, A. Reactions of nitric oxide and peroxynitrite with organic molecules and ferrihorseradish peroxidase: Interference with the determination of hydrogen peroxide. Free Radic. Biol. Med. 1996, 20, 373-381. [CrossRef]

59. Schön, T.; Hernandez-Pando, R.; Negesse, Y.; Leekassa, R.; Sundqvist, T.; Britton, S. Expression of inducible nitric oxide synthase and nitrotyrosine in borderline leprosy lesions. Br. J. Dermatol. 2001, 145, 809-815. [CrossRef]

60. Silva-Miranda, M.; WeK-Rodriguez, K.; Martinez, C.E.; Rojas-Espinosa, O. Expression of cyclooxygenase-2, alpha 1-acidglycoprotein and inducible nitric oxide synthase in the developing lesions of murine leprosy. Int. J. Exp. Path. 2006, 87, 485-494. [CrossRef]

61. Hernández-Pando, R.; Schön, T.; Orozco, E.H.; Serafín, T.; Estrada-Garcia, I. Expression of inducible nitric oxide synthase and nitrotyrosine during the evolution of experimental pulmonary tuberculosis. Exp. Toxic. Pathol. 2001, 53, 257-265. [CrossRef]

62. Izcue, A.; Coombes, J.L.; Powrie, F. Regulatory Lymphocytes and Intestinal Inflammation. Annu. Rev. Immunol. 2009, 27, 313-338. [CrossRef]

63. Sakaguchi, S.; Miyara, M.; Costantino, C.M.; Hafler, D.A. FOXP3+ regulatory T cells in the human immune system. Nat. Rev. Immunol. 2010, 10, 490-500. [CrossRef]

64. Plotkin, S.A. Correlates of Protection Induced by Vaccination. Clin. Vaccine Immunol. 2010, 17, 1055-1065. [CrossRef] [PubMed]

65. Wu, H.; Chen, Y.; Liu, H.; Xu, L.-L.; Teuscher, P.; Wang, S.; Lu, S.; Dent, A.L. Follicular regulatory T cells repress cytokine production by follicular helper T cells and optimize IgG responses in mice. Eur. J. Immunol. 2016, 46, 1152-1161. [CrossRef] [PubMed]

66. Jeyanathan, M.; Damjanovic, D.; Shaler, C.R.; Lai, R.; Wortzman, M.; Yin, C.; Zganiacz, A.; Lichty, D.; Xing, Z. Differentially imprinted innate immunity by mucosal boost vaccination determines antituberculosis immune protective outcomes, independent of T-cell immunity. Mucosal Immunol. 2013, 6, 612-625. [CrossRef] [PubMed]

67. Jeyanathan, M.; Shao, Z.; Yu, X.; Harkness, R.; Jiang, R.; Li, J.; Xing, Z.; Zhu, T. AdHu5Ag85A Respiratory Mucosal Boost Immunization Enhances Protection against Pulmonary Tuberculosis in BCG-Primed Non-Human Primates. PLoS ONE 2015, 10, e0135009. [CrossRef]

68. Afhami, S.; Drumond, V.A.; D'Agositnio, M.R.; Jeyanathan, M.; Gillgrass, A.; Xing, Z. Advancing Immunotherapeutic Vaccine Strategies Against Pulmonary Tuberculosis. Front. Immunol. 2020, 11, 557809. [CrossRef]

69. Torrado, E.; Robinson, R.T.; Cooper, A.M. Cellular response to mycobacteria: Balancing protection and pathology. Trends Immunol. 2011, 32, 66-72. [CrossRef]

70. Xu, X.; Gao, W.; Cheng, S.; Yin, D.; Li, F.; Wu, Y.; Sun, D.; Zhou, S.; Wang, D.; Zhang, Y.; et al. Anti-inflammatory and immunomodulatory mechanisms of atorvastatin in a murine model of traumatic brain injury. J. Neuroinflamm. 2017, 14, 167-182. [CrossRef]

71. Azeem, W.; Maukon, B.R.; Appel, S.; Maegrete, A.O.; Kalland, K.H. Dual Pro- and Anti-Inflammatory Features of MonocyteDerived Dendritic Cells. Front. Immunol. 2020, 11, 438-453. [CrossRef]

72. Sultana, S.; Bishay, B. Neutralization of TNFR-1 and TNFR-2 modulates S. aureus induced septic arthritis by regulating the levels of pro-inflammatory and anti-inflammatory cytokines during the progression of the disease. Immunol. Lett. 2018, $196,33-51$. [CrossRef]

73. Panigraphy, D.; Gilligan, M.M.; Huang, S.; Gartung, A.; Cortes-Puch, I.; Sime, P.J.; Phipps, R.P.; Serhan, C.H.N.; Hammock, B.D. Inflammation resolution: A dual-pronged approach to averting cytokine storms in COVID-19? Cancer Metastasis Rev. 2020, 39, 337-340. [CrossRef] 
74. Longhi, M.P.; Trumpfheller, C.; Idoyaga, J.; Caskey, M.; Matos, I.; Kluger, C.; Salazar, A.M.; Colonna, M.; Steinman, R.M. Dendritic cells require a systemic type I interferon response to mature and induce CD4+ Th1 immunity with poly IC as adjuvant. J. Exp. Med. 2009, 206, 1589-1602. [CrossRef]

75. Khader, S.A.; Guglani, L.; Rangel-Moreno, J.; Gopal, R.; Junecko, B.A.F.; Fountain, J.J.; Martino, C.; Pearl, J.E.; Tighe, M.; Lin, Y.-Y.; et al. IL-23 Is Required for Long-Term Control of Mycobacterium tuberculosis and B Cell Follicle Formation in the Infected Lung. J. Immunol. 2011, 187, 5402-5407. [CrossRef] [PubMed]

76. Choreño-Parra, J.A.; Bobba, S.; Rangel-Moreno, J.; Ahmed, M.; Mehra, S.; Rosa, B.; Martin, J.; Mitreva, M.; Kaushal, D.; Zúñiga, J.; et al. Mycobacterium tuberculosis HN878 Infection Induces Human-Like B-Cell Follicles in Mice. J. Infect. Dis. 2020, 221, $1636-1646$. [CrossRef] [PubMed]

77. Schmidt, E.G.; Haribhai, D.; Williams, J.B.; Aggarwal, P.; Jia, S.; Charbonnier, L.M.; Yan, K.; Lorier, R.; Turner, A.; Ziegelbauer, J.; et al. IL-10 produced by iTreg cells controls colitis and pathogenic ex. iTreg cells during immunotherapy. J. Immunol. 2012, 189, 5628-5648. [CrossRef]

78. Rubtsovo, Y.P.; Rasmussen, J.P.; Chi, Y.; Fontenot, J.; Castelli, I.; Ye, X.; Treuting, P.; Siewe, I.; Roers, A.; Henderson, W.R.J.; et al. Regulatory T cell-derived interleukin-10 limits inflammation at environmental interfaces. Immunity 2018, 28, 546-558. [CrossRef] [PubMed] 